\title{
SHARP LABORATORIES MEASUREMENTS I
}

\author{
JOHN G. ELLIS and RODMAN A. SHARP
}

\section{Sharp Laboratories Division, Beckman Instruments, La Jolla, California}

Radiocarbon measurements were begun at Sharp Laboratories in the spring of 1962 with the construction of a complete $\mathrm{C}^{14}$ dating laboratory. This first system used the method described by Fairhall, Schell, and Takashima (1961) for the conversion of $\mathrm{CO}_{2}$ to methane via ruthenium catalyst. This system proved to be fast and reliable, giving overall yields of solid sample to counting gas of better than $90 \%$ for the total conversion and purification (the conversion yield of $\mathrm{CO}_{2}$ to methane is quantitative). The detector in present use is $2 \mathrm{~L}$, with construction materials consisting solely of O.F.H.C. copper, teflon, and epoxy resin. The shield consists of 4 in. of high purity lead (specially prepared), 4 in. of borated hydrogenous neutron moderator, a guard counter (cosmic ray detector), and $1 \mathrm{in}$. of ultra pure mercury. The gross to net ratio obtained with this system averages about 53 . The background, for $P$ in $\mathrm{cm}$ methane pressure, is:

$$
\text { Background }=3.95 \pm .008+.00705 \mathrm{P}
$$

To avoid radon and tritium contamination problems with methane, $\mathrm{CO}_{2}$ and $\mathrm{H}_{2}$, all gases are specially prepared for us by Victor Equipment Company with only new cylinders and petrochemical sources for $\mathrm{CH}_{4}$ and $\mathrm{H}_{2}$. Ruthenium catalyst used for $\mathrm{CO}_{2}$ to methane conversion has sometimes been blamed by other workers for contamination problems in the final methane. However, this laboratory has investigated this possibility extensively and has never been able to trace contamination to this catalyst (Ellis and Sharp, unpub. ms.).

Presently under construction is a new system for $\mathrm{C}^{14}$ dating and low level tritium counting which will reduce the shield size and weight, reduce the background, and make available a rapid conversion to methane of both $\mathrm{C}^{14}$ labeled $\mathrm{CO}_{2}$ and $\mathrm{H}^{3}$ labeled $\mathrm{H}_{2} \mathrm{O}$ (Anand and Lal, unpub. ms.).

This new system is based on the reaction:

$$
\text { 4. } \mathrm{Zn}+\mathrm{CO}_{2}+2 \mathrm{H}_{2} \mathrm{O} \rightarrow \mathrm{CH}_{4}+4 \mathrm{ZnO}
$$

This reaction is also quantitative and yields of better than $90 \%$ from solid sample to counting gas are obtained. At the present time we can measure 20 T.U. without enrichment, with an accuracy of $10 \%$, and hopefully this will improve as more data is accumulated.

Measurements made by this laboratory are based on the value $5570 \pm 30$ yr for the half life of $\mathrm{C}^{14}$, and $95 \%$ the activity of oxalic acid as the modern standard, in agreement with the decision of the Fifth Radiocarbon Dating Conference. The Heidelberg $\mathrm{Na}_{2} \mathrm{CO}_{3}$ standard solution with an absolute specific activity of $139.6 \pm 1.3 \mathrm{DPM} \mathrm{C}^{14}$ per $\mathrm{g}$ of $\mathrm{C}$ gave a corrected counting rate of $128.1 \pm .039 \mathrm{cpm}$. This gives a counting efficiency of $92 \%$ and a conversion factor to NBS oxalic acid of 9.65.

All samples dated by this laboratory so far have been measured for the purpose of intercomparison with other established laboratories. Two of these samples are 1710 wood and wood from the tomb of King Zoser. 


\section{SAMPLE DESCRIPTIONS}

\section{SL-3. Sequoia}

Wood from between the 230th and 250th growth rings. Tree was cut 26 February 1961. Sample supplied by Scripps Inst. of Oceanography.

\section{SL-8. Zoser's Tomb, Egypt}

$4020 \pm 100$

2070 в.C.

Sycamore wood from roof of tomb of $S$ enclosure, of the step pyramids of Sakkara, the time of King Zoser. Sample supplied by A. E. Bainbridge.

Comment: this sample (Kusumgar et al., 1963) previously dated by:
(1) Bombay
$3990 \pm 110$
(2) La Jolla 4080
(3) Arizona $4240 \pm 150$
(4) Chicago $3979 \pm 350$

\section{REFERENCES}

Fairhall, A. W., Schell, W. R., and Takashima, Y., 1961, Apparatus for methane synthesis for radiocarbon dating: Rev. Sci. Instruments, v. 32, no. 3, p. 323-325.

Kusumgar, S., Lal, D., and Sarna, R. P., 1963, Tata Institute radiocarbon date list I: Radiocarbon, v. 5, p. 273-282. 